\title{
AN INVESTIGATION ON TRADE OPENNESS, FISCAL POLICY AND ECONOMIC GROWTH IN MALAYSIA: USING AN ARDL BOUNDS TESTING APPROACH
}

\author{
HUSSIN ABDULLAH \\ MUSZAFARSHAH MOHD MUSTAFA \\ College of Arts and Sciences \\ Universiti Utara Malaysia \\ MUZAFAR SHAH HABIBULLAH \\ Faculty of Economics and Management \\ Universiti Putra Malaysia
}

\begin{abstract}
This study examines the impacts of trade openness and fiscal policy on economic growth in Malaysia between 1970 and 2003 using the autoregressive distributed lag (ARDL) approach and bounds test as proposed by Pesaran et al. (2001). Based on a structure consistent with the endogenous growth theory, the $A R D L$ results show that, overall, trade openness and fiscal policy have strong positive impacts on economic growth in Malaysia over this period. This paper also develops a system instrumental variable method to estimate the structural speed of adjustment coefficient in an error correction model.
\end{abstract}

Keywords: Economic growth; Trade openness; Fiscal policy; Government expenditure; Autoregressive Distributed Lag (ARDL).

JEL Classification: C23, F15, H30, H50, O47.

\begin{abstract}
ABSTRAK
Kajian ini adalah untuk memeriksa impak keterbukaan dagangan dan polisi fiskal ke atas pertumbuhan ekonomi Malaysia di antara tahun 1970 dan 2003 melalui pendekatan autoregrasi lat tertabur ( $A R D L$ ) dan ujian sempadan (bounds test) yang diperkenalkan oleh Pesaran et al. (2001). Berdasarkan struktur yang tidak berubah dengan teori pertumbuhan tempatan (endogenous growth
\end{abstract}


theory), kami dapati bahawa keputusan ARDL menunjukkan bahawa secara keseluruhannya keterbukaan dagangan dan polisi fiskal mempunyai impak positif yang kuat ke atas pertumbuhan ekonomi Malaysia sepanjang tempoh masa yang dikaji. Kajian ini juga membina satu kaedah sistem pembolehubah instrumen untuk menganggar struktur kelajuan pelarasan koefisyen dalam mekanisme pembetulan ralat (ECM).

\section{INTRODUCTION}

The relationship between the openness of a country and its economic growth has been a widely debated topic, theoretically and empirically. Based on the comparative advantage theory, a country will export products that have comparative advantage and import goods that have no comparative advantage. This will lead to an increase in efficiency that will support the country's economic growth. Thus, trade openness, through export and import, has succeeded in supporting economic growth. Vamvakidis (1998) notes that most of the literature on trade "and growth tries to explain why frees trade foster growth. While the static impacts of trade liberalization and globalization are assessed theoretically through its impact on trade creation and trade diversion, the effects over the short and medium terms are used to capture its impact on growth.

For those who are against liberalization and globalization, protection is believed to be the correct approach to enhance economic growth of a country. According to this view, a country's inability to compete -internationally in exports and the lack of readiness in opening up its market will aggravate its economic situation. The question regarding the "benefits of openness to a country's economy has been mooted once again due to the 1997/98 Asian financial crisis. Not only economic openness will cause a country to be more vulnerable towards external shocks but its inability to compete with other countries will also put the nation at a disadvantage, economically.

The openness of the Malaysian economy in terms of total trade to gross domestic product (GDP) has increased over time. The average value of total trade to GDP ratio over the 1970-1979 period was 88.6 percent. But the average ratio has increased to 113.1 percent over the 1980-1989 period and 178.2 percent over the 1990-1999 period. In 2000, the ratio was 230.8 percent. Liberalization and globalization of the world economy is expected to increase the openness of the Malaysian economy. Malaysia 
has achieved high economic growth rates since 1970s, and one of the success stories in Southeast Asia. The average economic growth rate per annum in Malaysia over the periods 1970-1979, 1980-1989 and 1990-1999 were 8.4 percent, 5.8 percent and 7.2 percent, respectively. The economic growth in Malaysia has remained impressive even after the Asian financial crisis in 1997-1998. The economic growth rate of Malaysia was 6.3 percent in 2007.

The four main components of fiscal policy are (i) expenditure/budget reform (ii) revenue (particularly tax revenue) mobilization, (iii) deficit containment/ financing and (iv) to determine fiscal transfers from higher to lower levels of governments. Fiscal policy works through both aggregate demand and aggregate supply channels. Changes in total taxes and public expenditure affect the level of aggregate demand in the economy, whereas, the structure of taxation and public expenditure affect, among others, the incentives to save and invest (at home and abroad), risk-taking activities, and export and import of goods and services (Jha, 2007).

The role of fiscal policy in influencing economic activities has been debated by academicians and policy-makers for a long time and has played an increasingly important role in many developing countries. Malaysia has pursued an expansionary fiscal policy, from time to time, to stimulate growth. During episodes of high inflations, strong fiscal contractionary measures are applied. Budget deficits are usually kept low except during recent events.

The objective of this study is to examine the long run relationships between trade openness, fiscal policy and economic growth in Malaysia. We utilized the autoregressive distributed lag (ARDL) bounds test methodology of Pesaran et al. (2001). This paper is organized as follows. Section 2 contains a brief literature review. We illustrate the application of our models on the Malaysian economy in Section 3. Section 4 presents the empirical results and Section 5 concludes.

\section{REVIEW OF SELECTED LITERATURE}

There are many measures of trade openness such as trade shares over GDP, population densities, trade barriers, bilateral payment arrangements and exchange rate - the black market premium and indices of trade orientation (Yanikkaya, 2003). However, none of these measures is free 
of methodological problems (Harrison, 1996 \& Yanikkaya, 2003). One of the measures, which is widely used in the literature, is trade shares over GDP or more specifically, exports plus imports divided by GDP. This measure is usually available to a country and over a long period of time. However, this measure has some limitations since it is dependent on resource endowments, country size and many other determinants of trade. A country may have a high trade ratio because of its small size or has resources which are valuable rather than because it has low restrictions on trade with other countries (Lloyd, 1999). Nonetheless, many empirical studies have employed this measure and reported a significant positive impact on economic growth. The use of this measure is said to be an important step towards understanding the relationship between trade and economic growth as proposed by the new growth and new trade theories (Yanikkaya, 2003).

The impact of trade openness on economic growth could be sensitive to the variables measuring trade openness and other explanatory variables used in the empirical model. Harrison (1996) finds that not all of the -measures of trade openness are significant, although most of them exhibit positive impacts on economic growth. Thus, one of the solutions is to employ as many different measures of openness to trade in a study (Harrison, 1996; Vamvakidis, 2002; Yanikkaya, 2003). However, most of the measures of openness to trade are not available for developing countries or are limited by sample size. Thus, their usage in a long-run "analysis is limited.

Harrison (1996) examines the relationship between trade openness and economic growth in developing countries using cross section and panel data for the period from 1960 to 1987. The empirical estimation is based on an augmented production function. The results suggest the importance of analyzing the short-run and long-run impacts of trade openness on economic growth. Edwards (1998), amongst others, reports that trade openness has a positive impact on economic growth.

The theoretical and empirical literature on fiscal policy and economic growth is rich and growing. They show that economic growth is significantly affected by fiscal policies, although there are some disagreements on the signs of the effects. Caselli et al. (1996) find a robust positive contribution of the government expenditure ratio (net of defense and educational expenditure) to growth. Similarly, Kneller et al. (1999) find that public expenditure and taxation affect growth if they are productive and distortionary, respectively. Productive government expenditure is found to positively affect growth, whereas distortionary 
taxation tends to be harmful to growth. Thus, they argue that both sides of the government budget should be considered in estimating the impact of fiscal policy on growth, as their financing offset the growthenhancing effect of productive expenditure. Gerson (1998) surveys the theoretical and empirical literature on the effects of fiscal policy variables (government expenditure program and taxes) on economic growth. He concludes that educational attainment and public health status have significant positive effects on per capita output growth. Also, he finds that economies that are open to trade tend to grow faster than those that are closed. Therefore, fiscal policies that promote openness would encourage growth.

In recent years, some researchers of international econometric studies have found a significant negative effect of taxation on long-term GDP growth. A study by Cashin (1995) on 23 OECD countries over the 19711988 period has found that a 1\% increase in tax to GDP ratio lowers output per worker by $2 \%$. Another study by Engen and Skinner (1993) on US modeling together with a sample of OECD countries finds that a $2.5 \%$ increase in tax to GDP ratio reduces GDP growth by $0.2 \%$ to $0.3 \%$. While studying on 17 OECD countries over the 1970-1994 period, Bleaney et. al. (2001) find that a 1\% increase in distortionary tax revenue reduces GDP growth by $0.4 \%$. Using a sample of rich OECD/non-OECD countries over the 1970-1995 period, Folster and Henrekson (2001) find that a $10 \%$ increase in tax to GDP ratio reduces GDP growth by $1 \%$.

In looking into the relationship between government expenditure and economic growth, it has becoming of crucial importance to divide government activities into several categories and methodologies. A study by Yasin (2003), on the relationship between government expenditure and economic growth, finds that government spending, trade-openness, and private investment spending have positive and significant effects on economic growth. Other studies by Barro and Sala-i-Martin (1995), Devarajan et al. (1996), Glomm and Ravikumar (1997), Landau (1997), Hansson and Henrekson (1994), and Chen and Gupta (2006), on government expenditure for human capital such as education, health, and other services, find a significant positive effects of these expenditure on growth.

\section{EMPIRICAL SPECIFICATION}

We employ the method of Hoeffler (2002) to introduce the policy related variables in the Solow model. We introduce government expenditure 
and other fiscal variables as proxies for policy related variables. The government expenditure and other fiscal variables state that the difference between government expenditure on health, education, distortionary taxation, budget balance, aggregate of other independent fiscal variables and aggregate of independent government expenditure variables. We also include a trade variable, defined as the import plus export share of GDP, because Levine and Renelt (1992), using sensitivity analysis, find that only trade variables (such as the import plus export share of GDP and other measures of openness) explain investment robustly.

Therefore, the basic model for the government expenditure and other fiscal variables as proxies for policy related variables takes the following form:

$$
\ln Y_{t}=\beta_{0}+\beta_{1} \text { GOVPOL }_{t}+\beta_{2} \ln S_{k t}-\beta_{3} \ln (n+g+\delta)_{t}
$$

where $Y_{t}$ is real GDP per capita, GOVPAL is a control variables of government expenditure and other fiscal variables, $S_{k t}$ is the savings in "physical capital, $(n+g+\delta)$ : is the rate of labor growth, $g$ is the rate of technology growth or technological progress and $\delta$ is the rate of depreciation. The addition of $g$ and $\delta$ are assumed to be constant across countries and over time as in Islam (1995), Mankiw et al. (1992) and Caselli et al (1996), technological progress and the depreciation rate are assumed to be constant across countries. The given figure is 0.05 and it is applied in this paper. $\beta_{0}$ is a constant term $\beta_{1}, \beta_{2}$ and $\beta_{3}$ and are estimated parameters in the model.

-In this section, the discussion is focused on the expansion explanatory -variables in openness, fiscal policy, and economic growth. Equation (1) is extended and formed into three models as follows;

Model (1)

$$
\begin{gathered}
\ln r g d p c_{t}=\beta_{0}+\beta_{1} \ln h e_{t}+\beta_{2} \ln e e_{t}+\beta_{3} \ln \text { open }_{t}+\beta_{4} \ln O F V_{t} \\
+\beta_{5} \ln S_{k t}-\beta_{6} \ln (n+g+\delta)_{t}+\varepsilon_{t}
\end{gathered}
$$

Model (2)

$$
\begin{aligned}
\ln r g d p c_{t} & =\beta_{0}+\beta_{1} \ln d t_{t}+\beta_{2} \ln b b_{t}+\beta_{3} \ln \text { open }_{t}+\beta_{4} \ln G E_{t}+\beta_{5} \ln S_{k t} \\
& -\beta_{6} \ln (n+g+\delta)_{t}+\varepsilon_{t}
\end{aligned}
$$




$$
\begin{aligned}
\ln r g d p c_{t} & =\beta_{0}+\beta_{1} \ln \text { open }_{t}+\beta_{2} \ln G E_{t}+\beta_{3} \ln O F V_{t}+\beta_{4} \ln S_{k t} \\
- & \beta_{5} \ln (n+g+\delta)_{t}+\varepsilon_{t}
\end{aligned}
$$

where $Y_{t}$ is real GDP per capita, $h e_{t}$ is government expenditure on health to GDP, $e e_{t}$ represents government expenditure on education to GDP, open $_{t}$ is trade openness to GDP, $d t_{i t}$ is distortionary taxation as a share of GDP (obtained by taxes on income and profit + social contribution + taxes on payroll + taxes on property), $b b_{i t}$ represents budget balance as a share of GDP [obtained by (tax revenue + non-tax revenue + grants) - (current expenditure + capital expenditure (minus government expenditure on health and education)], $O F V_{t}$ is aggregate of other independent fiscal variables as a share of GDP (obtained by summing up public sector wages and salaries, expenditure on other goods and services, transfers and subsidies, interest payment on government debt, capital expenditure (minus government expenditure on health, and education), tax revenue, non-tax revenue, and grant), $G E_{t}$ is aggregate of independent government expenditure variables as a share of GDP (obtained by summing up the government expenditure on health and education), $S_{k t}$, and $(n+g+\delta)$ are as defined earlier in Equation (5), $t$ is time series data, and $\varepsilon_{t}$ is an error term. The constant is denoted by $\beta_{0}$ while $\beta_{1}-\beta_{6}$ are the coefficients that show how much a one unit increase in each individual variable will affect the growth rate of the economy.

In Model 1, the priority is assigned to health and education expenditure, trade openness and other fiscal variables. The Federal government expenditure in Malaysia accounted for over $80 \%$ of total government expenditure (Federal + State expenditure). This is an important characteristic of the government expenditure in Malaysia which is dominated by the spending of the Federal government. Some literature look into government expenditure that increases human capital and expenditure that contributes to innovation, such as for research and development, as the core expenditure since it enhances the human capital base (investment) and technological progress. We also believe that the openness of the Malaysian economy is also one of the important factors that promote economic growth. In Model 2, we give a priority to distortionary taxation and budget balance. The fiscal policy stances can be read from the changes in the distortionary taxation or the fiscal balance. The improvements in the Government's budget management and planning may strengthen the link between fiscal policy and growth. In evaluating the impact of fiscal policy on growth, the structures of both taxation and expenditure should be taken into account together with non-economic factors. 


\section{ARDL Bound Testing Approach}

In applying the co-integration technique, we need to determine the order of co-integration of each variable. However, as noted in the literature, depending on the power of the unit root tests, different tests yield different results. In view of this problem, Pesaran and Shin (1995) and Perasan, et al. (2001) introduce a new method of testing for cointegration. This approach is known as the autoregressive distributed lag (ARDL) approach. The main advantage of this approach lies in the fact that it obviates the need to classify variables into $I(1)$ or $I(0)$. The test involves three steps. First, we estimate each equation by using ordinary least square (OLS) technique. Second, we calculate Wald test (F-statistic) to discern the long-run relationships between the concerned variables. Wald test can be conducted by imposing restrictions on the estimated -long-run coefficients.

Using the assumptions made by Pesaran et al. (2001) in Case III (unrestricted intercepts and no trend) and imposes the restriction, (1) $\lambda_{y x}=0, \mu \neq 0$, the relationships between the dependent variable and independent variables in Equation (6) to Equation (8) become;

$$
\begin{aligned}
\ln r g d p c_{t}= & \beta_{0}+\beta_{1} \ln r g d p c_{t-1}+\beta_{2} \ln h e_{t-1}+\beta_{3} \ln e e_{t-1}+\beta_{4} \ln \text { open }_{t-1}+\beta_{5} \ln O F V_{t-1} \\
& +\beta_{6} \ln S_{k}+\beta_{7} \ln (n+g+\delta)_{t-1}+\beta_{8, i} \sum_{i=1}^{p} \Delta \ln r g d p c_{t-i}+\beta_{9, i} \sum_{i=1}^{q_{1}} \Delta \ln h e_{t-i} \\
& +\beta_{10, i} \sum_{i=1}^{q_{2}} \Delta \ln e e_{t-i}+\beta_{11, i} \sum_{i=1}^{q_{3}} \Delta \ln \text { open }_{t-i}+\beta_{12, i} \sum_{i=1}^{q_{4}} \Delta \ln O F V_{t-i}+\beta_{13, i} \sum_{i=1}^{q_{5}} \Delta \ln S_{k} t_{t-i} \\
& +\beta_{14} \sum_{i=1}^{q_{6}} \Delta \ln (n+g+\delta)_{t-i}+\varepsilon_{t} \\
\ln r g d p c_{t}= & \beta_{0}+\beta_{1} \ln r g d p c_{t-1}+\beta_{2} \ln d t_{t-1}+\beta_{3} \ln b b_{t-1}+\beta_{4} \ln o p e n_{t-1}+\beta_{5} \ln G E_{t-1}+ \\
& +\beta_{6} \ln S_{k}+\beta_{7} \ln (n+g+\delta)_{t-1}+\beta_{8, i} \sum_{i=1}^{p} \Delta \ln r g d p c_{t-i}+\beta_{9, i} \sum_{i=1}^{r_{1}} \Delta \ln d t_{t-i} \\
& +\beta_{10, i} \sum_{i=1}^{r_{2}} \Delta \ln b b_{t-i}+\beta_{11, i} \sum_{i=l}^{r 3} \Delta \ln o p e n_{t-i}+\beta_{12, i} \sum_{i=1}^{r_{4}} \Delta \ln G E_{t-i}+\beta_{13, i} \sum_{i=1}^{r_{5}} \Delta \ln S_{k}{ }_{t-i} \\
& +\beta_{14} \sum_{i=1}^{r_{6}} \Delta \ln (n+g+\delta)_{t-i}+\varepsilon_{t} \\
\ln r g d p c_{t}= & \beta_{0}+\beta_{1} \ln r g d p c_{t-1}+\beta_{2} \ln o p e n_{t-1}+\beta_{3} \ln G E_{t-1}+\beta_{4} \ln O F V_{t-1}+\beta_{5} \ln S_{k}{ }_{t-1} \\
& +\beta_{6} \ln (n+g+\delta)_{t-1}+\beta_{7, i} \sum_{i=1}^{p} \Delta \ln r g d p c_{t-i}+\beta_{8, i} \sum_{i=1}^{s_{1}} \Delta \ln o p e n_{t-i} \\
& +\beta_{9, i} \sum_{i=1}^{s_{2}} \Delta \ln G E_{t-i}+\beta_{10, i} \sum_{i=1}^{s_{3}} \Delta \ln O F V_{t-i}+\beta_{11, i} \sum_{i=1}^{r_{4}} \Delta \ln S_{k}{ }_{t-i} \\
& +\beta_{12} \sum_{i=1}^{r_{5}} \Delta \ln (n+g+\delta)_{t-i}+\varepsilon_{t}
\end{aligned}
$$

Where $\Delta$ is the first difference operator, $u_{t}$ is white noise disturbance term and all variable are expressed in logarithms. Equation (9) to Equation (11) can also be interpreted as an Autoregressive Distributed Lag (ARDL) $\left(p, q_{1^{\prime}}, q_{2^{2}}, q_{3^{\prime}} q_{4^{\prime}}, q_{5^{\prime}} q_{6}\right),\left(p, r_{1}, r_{2}, r_{3}, r_{4}, r_{5}, r_{6}\right)$ and $\left(p, s_{1^{\prime}}, S_{2^{\prime}}, s_{3^{\prime}}, s_{4^{\prime}} s_{5}\right)$ models, respectively. We apply Schwarz Bayesian Criteria (SBC) for the possibility of different lag lengths. From the estimation of unrestricted error correction model, 
the long-run elasticities are the coefficient of the one lagged explanatory variables (multiplied with a negative sign) divided of the one lagged dependent variable.

We estimate Equation (9) to Equation (11) by Ordinary Least Squares (OLS) technique and then calculate the F-statistic (Wald test) for the existence of long-run relationships between the concerned variables. The null and alternative hypotheses are constructed as follows:

$$
\begin{aligned}
& H_{0}: \beta_{1}=0 \text { and } \beta_{2}=\beta_{3}=\ldots=\beta_{6}=0 \text { (no long-run levels relationship) } \\
& H_{A}: \beta_{1} \neq 0 \text { and } \beta_{2} \neq \beta_{3} \neq \ldots \neq \beta_{6} \neq 0 \text { (long-run levels relationship exist) }
\end{aligned}
$$

Third, we follow the bounds test approach [Table $3 \mathrm{CI}(\mathrm{iii})]$ suggested by Pesaran et al. (2001) and if our sample test statistic is below the associated lower critical value, it means that we accept the null hypothesis at a particular significance level. The null hypothesis is then accepted regardless of whether the underlying orders of integration of government expenditure and economic growth are $I(0)$ or $I(1)$. According to Pesaran, et al. (2001), the lower bound critical values assume that the explanatory variables, $x_{t}$ are integrated of order zero, or I(0), while the upper bound critical values assume that $x_{t}$ are integrated of order one, or I(1). Therefore, if the computed F-statistic from our sample test statistic exceeds the upper bound value, it means that we reject the null in favor of the alternative that there exists a long-run relationship between the government expenditure and economic growth. Conversely, if the computed F-statistic from our sample test statistic is smaller than the lower bound value, then we do not reject the null hypothesis and we conclude that economic growth and its determinants are not cointegrated. Otherwise, if the computed F-statistic from our sample test statistic falls between the lower and upper bound value, the results are inconclusive at this particular significance level.

Finally, the error correction model can be defined within the ARDL framework as follows;

$$
\begin{aligned}
\ln r g d p c_{t}=\mu & +\sum_{i=1}^{p} \phi_{i} \Delta \ln r g d p c_{t-i}+\sum_{j=1}^{q_{1}} \varphi_{l} \Delta \ln h e_{t-j}+\sum_{m=1}^{q_{2}} \gamma_{m} \Delta \ln e e_{t-m} \\
& +\sum_{p=1}^{q_{3}} \eta_{p} \Delta \ln \text { open }_{t-p}+\sum_{s=1}^{q_{4}} \kappa_{s} \Delta \ln O F V_{t-s}+\sum_{w=1}^{q_{5}} \lambda_{w} \Delta \ln S_{k}{ }_{t-w} \\
& +\sum_{y=1}^{q_{6}} \pi_{y} \Delta \ln (n+g+\delta)_{t-y}+\psi e c m_{t-1}+\varepsilon_{t} \\
\ln r g d p c_{t}=\mu & +\sum_{i=1}^{p} \phi_{i} \Delta \ln r g d p c_{t-i}+\sum_{j=1}^{r_{1}} \varphi_{l} \Delta \ln d t_{t-j}+\sum_{m=1}^{r_{2}} \gamma_{m} \Delta \ln b b_{t-m} \\
& +\sum_{n=1}^{r_{4}} \kappa_{n} \Delta \ln \text { open }_{t-n}+\sum_{p=1}^{r_{5}} \eta_{p} \Delta \ln G E_{t-p}+\sum_{w=1}^{r_{6}} \lambda_{w} \Delta \ln S_{k} t_{t-w} \\
& +\sum_{y=1}^{r_{7}} \pi_{y} \Delta \ln (n+g+\delta)_{t-y}+\psi e c m_{t-1}+\varepsilon_{t}
\end{aligned}
$$




$$
\begin{aligned}
\ln r g d p c_{t}=\mu & +\sum_{i=1}^{p} \phi_{i} \Delta \ln r g d p c_{t-i}+\sum_{j=1}^{s_{1}} \varphi_{l} \Delta \ln \text { open }_{t-j}+\sum_{m=1}^{s_{2}} \gamma_{m} \Delta \ln G E_{t-m} \\
& +\sum_{p=1}^{s_{3}} \eta_{p} \Delta \ln O F V_{t-p}+\sum_{w=1}^{s_{5}} \lambda_{w} \Delta \ln S_{k}{ }_{t-w} \\
& +\sum_{y=1}^{s_{6}} \pi_{y} \Delta \ln (n+g+\delta)_{t-y}+\psi e c m_{t-1}+\varepsilon_{t}
\end{aligned}
$$

Here $(\phi, \varphi, \gamma, \eta, \kappa, \lambda, \pi)$ in Equation (12) to Equation (14) is referring to the short run dynamic coefficients and $v$ denote the speed of adjustment.

\section{DATA AND CHOICE OF VARIABLES}

The data set consists of a time series of observations for Malaysia from -1970 - 2003. Annual data on real GDP, real per capita GDP, government Jexpenditure on education and health, distortionary taxation, and budget balance (all expressed as ratios to GDP) are collected from WDI (World Development Indicator), ADB (Asian Development Bank), D) and GFS (Government Finance Statistics). We also used an aggregate of independent government expenditure variables as a share of GDP (obtained by summing up the government expenditure on health and education), and an aggregate of other independent fiscal variables as a share of GDP (obtained by summing up public sector wages and salaries, expenditure on other goods and services, transfers and subsidies, interest payment on government debt, capital expenditure (minus government "expenditure on health and education), tax revenue, non-tax revenue, Dand grant. We also used the data on trade openness level as a share of GDP and proxied the saving rate by the aggregate investment (real gross capital formation) to GDP ratio and proxied the average of the total labor force as an average population growth rates. Like Islam (1995), Mankiw -et al. (1992), and Caselli et al. (1996), technological progress and the depreciation rate are assumed to be constant across countries and that they sum up to 0.05 . This figure (0.05) is already included in the natural logarithm of the sum of population growth $[1 \mathrm{n}(n+g+\delta)$.].

\section{EMPIRICAL RESULTS}

To ensure that there are long term relationships among the variables in the models, the Augmented Dickey-Fuller (ADF) test for stationarity is carried out for all variables. If the variables found in Equation (6) to Equation (8) have the same level of stationarity that is $I(1)$, then long run relationship or co-integration may exist between variables in the 
equations. The existence of co-integration means that the result of the regression in Equation (6) to Equation (8) is not a spurious regression and it forms a similar wave in the long term.

Table 1 reports the statistics for unit root for each series in the time series. The empirical results show that we cannot reject the existence of unit root in almost all variables at a significant statistical conventional level in both constant and constant plus trend and the budget balance $(b b)$ in constant plus trend. This means that budget balance $(b b)$ is stationary in level. The results also show that technological progress and the depreciation rate $(n+g+\delta)$ is stationary in level: $\mathrm{I}(0)$. The ADF test is carried out again in first difference approach and the result is reported in Table 1. This result demonstrates that almost all series are stationary at $1 \%$ significance level: I(1).

It is clear from the empirical results in Table 1, under these circumstances and especially when we faced mix results, applying the ARDL bounds approach is the efficient way of determining the long-run relationships among the variables under investigation.

Table 1

The Augmented Dickey-Fuller (ADF) Test for a Unit Root

\begin{tabular}{lcc|cc}
\hline & \multicolumn{2}{c|}{$\mathrm{I}(0)$} & \multicolumn{2}{c}{$(1)$} \\
\hline & Constant & Constant + Trend & Constant & Constant + Trend \\
\hline 1n rgdpc & -1.367552 & -1.751690 & $-4.715820^{*}$ & $-4.851679^{*}$ \\
1n $h e$ & -1.892942 & -1.527261 & $-4.808152^{*}$ & $-5.010242^{*}$ \\
1n $e e$ & -1.051425 & -1.765209 & $-4.221931^{*}$ & $-4.502820^{*}$ \\
1n $d t$ & -1.556586 & -1.970450 & $-3.539291^{*}$ & $-4.190435^{*}$ \\
1n $b b$ & -1.423561 & $-3.303500^{* * *}$ & $-5.829779^{*}$ & - \\
1n open & -0.018342 & -2.564113 & $-5.263357^{*}$ & $-5.168119^{*}$ \\
1n GE & -1.143818 & 0.130965 & $-3.296265^{* *}$ & $-3.337086^{*}$ \\
1n FP & -1.784892 & -1.975155 & $-4.780655^{*}$ & $-5.253306^{*}$ \\
1n $s_{k}$ & -1.241665 & -1.866358 & $-4.589701^{*}$ & $-4.738400^{*}$ \\
1n $(n+g+\delta)$ & $-3.190299^{* *}$ & $-3.159200^{* *}$ & - & - \\
\hline
\end{tabular}

Figure in parentheses ( ) refers to the selected lag length. The number of lag was selected based on Akaike Information Criterion (AIC). The null hypothesis is that the series is non-stationary and the rejection of null hypothesis for ADF test is based on the MacKinnon (1991) critical value.

* Significant at $1 \%$ level.

** Significant at $5 \%$ level.

*** Significant at $10 \%$ level. 


\section{Co-integration tests}

The co-integration test in the bounds' framework involves the comparison of the F-statistics against the critical values, which are generated for specific sample sizes (Narayan, 2005). The bounds test for Model (1) to Model (3) for Malaysia is presented in Table 2. Using the asymptotic critical value computed by Pesaran et al. (2001), we find that all the test statistics are significant at the 1\% level for Model (1) and Model (3). These results lead us to reject the null hypothesis of no co-integration, regardless of whether the variables are $I(1)$ or $I(0)$ or a mix of both. The test also indicates the presence of valid long run relationships between the independent variables and the dependent variable in Model (1) and Model (3) at the calculated F-statistic of 4.638 and 13.063 which exceed the upper critical value. Model (2) shows that the calculated F-statistic is 1.395 which is not significant at any levels, indicating that there are no long run relationships between the independent variables and dependent variable.

\section{-Table 2}

Bounds Test for the Existence of a Long-run Relationship

\begin{tabular}{cc}
\hline Model & F-Statistic \\
\hline Model (1) & $4.638^{*}$ \\
\hline Model (2) & 1.395 \\
Model (3) & $13.063^{*}$ \\
\hline
\end{tabular}

\begin{tabular}{lc|c|c|c}
\hline & \multicolumn{4}{c}{ CRITICAL VALUE } \\
\cline { 2 - 5 } & \multicolumn{2}{c}{ LOWER } & \multicolumn{2}{c}{ UPPER } \\
\cline { 2 - 5 } & Model (1) & Model (2) & Model (1) & Model (2) \\
\cline { 2 - 5 } $1 \%$ significance level & 3.15 & 3.41 & 4.43 & 4.68 \\
$5 \%$ significance level & 2.45 & 2.62 & 3.61 & 3.79 \\
$10 \%$ significance level & 2.12 & 2.26 & 3.23 & 3.35 \\
\hline
\end{tabular}

Note. The critical values are taken from Pesaran et al. (2001), Table CI(iii) Case III: Unrestricted intercept and no trend. ${ }^{*}{ }^{* *}$ and ${ }^{* * *}$ denote significant at $1 \%, 5 \%$ and $10 \%$ significance levels.

To ascertain the goodness of the ARDL model, the diagnostic test and the stability test are conducted. Table 3 shows that Model (1) and Model (3) generally pass the the Breusch-Godfrey Serial Correlation LM test, Jacque-Bera normality test, Ramsey RESET stability test and ARCH test in the first stage except for Model (2). These tests show that there is no evidence of autocorrelation and that the models pass the tests for 
normality and thus proving that the error is normally distributed. Model (2) shows that the model has a serial correlation even though it passes other tests, meaning that this model does not has the goodness of fit of the ARDL model. Finally, when analyzing the stability of the long-run coefficients together with the short-run dynamic model, the cumulative sum of recursive residuals (CUSUM) and the cumulative sum of squares of recursive residual (CUSUMSQ) are applied. According to Pesaran and Pesaran (1997), the stability of the estimated coefficients of the models should be empirically investigated. A graphical representation of CUSUM and CUSUMSQ statistics are shown in Appendix 1. It is clear from Appendix 1, that the plots of both the CUSUM and the CUSUMSQ are within the boundaries and hence these statistics confirm the stability of the long-run coefficients of the openness, fiscal policy and economic growth in ARDL models.

\section{Table 3}

Diagnostic Checking for ARDL Model

\begin{tabular}{l|ccc}
\hline & Model (1): & Model (2): & Model (3): \\
& ARDL $(2,2,2,1,2,1,2)$ & ARDL $(2,2,2,2,2,2,2)$ & ARDL $(1,1,2,1,0,2)$ \\
\hline LM Test & $2.607(0.205)$ & $6.943(0.022)$ & $2.042(0.232)$ \\
Jarque-Bera & $0.724(0.696)$ & $0.719(0.698)$ & $0.267(0.876)$ \\
Ramsey's RESET Test & $12.385(0.039)$ & $8.598(0.013)$ & $9.171(0.011)$ \\
ARCH & $1.325(0.259)$ & $1.370(0.251)$ & $0.580(0.452)$ \\
\hline
\end{tabular}

Notes.

Ramsey's RESET test using the square of the fitted values.

ARCH - Based on the regression of squared residuals on squared fitted values (Engle 1982).

Jarque-Bera - refer to normality test which is based on a test of skewness and kurtosis of residuals.

LM test - refer to Autocorrelation Breusch-Godfrey Serial Correlation.

\section{Long-Run and Short-Run Estimations}

In the first step of analysis of ARDL, the existence of the long run coefficients of Equation (6) to Equation (8) [or Model (1) to Model (3)], using Equation (9) to Equation (11), are estimated and the results are reported in Table 4. As discussed earlier, one of the important issues in applying the ARDLis the choice of the order of the distributed lag function. In order to select the best performing ARDL-model, the significance of the resulting ARDL-VECM parameters, the Schwarz Bayesian Criterion $(\mathrm{SBC})$ is preferred to other models specification criteria because it tends 
to define more parsimonious specifications: the small data sample in the current study underlies this preference (Pesaran and Smith, 1998). The SBC lag specifications for Model (1) to Model (3) are shown in Table 5 . For these three models, the optimal numbers of lags for each of the variables are shown as $\operatorname{ARDL}(2,2,2,1,2,1,2), \operatorname{ARDL}(2,2,2,2,2,2,2)$, and ARDL $(1,1,2,1,0,2)$ respectively.

As presented, the long-run coefficients for models (1) to (3) follow a similar pattern. The results show that the health expenditure (1n he) and education expenditure (1n ee) variables in Model (1) have a statistically significant effects on real GDP per capita (economic growth). A 1\% increase in these variables lead to a $8.29 \%$ and $9.42 \%$ increase in economic growth, respectively. The openness variable (1n open) has a significant effect on economic growth at $5 \%$ level; a 1\% increase in openness leads to an increase in economic growth by $4.44 \%$. The coefficient of fiscal policy $(1 \mathrm{n} F P)$ in Malaysia is statistically significant. If we consider the effect of fiscal policy on economic growth, a $1 \%$ increase in fiscal policy leads to a $6.19 \%$ increase in economic growth. The estimate of the coefficient for the savings in physical capital (investment) $\left(1 \mathrm{n} s_{k}\right)$ is positive and "statistically significant in Model (1); a 1\% increase in savings leads to a $7.65 \%$ increase in economic growth. The coefficient of population growth $(1 \mathrm{n}(n+g+\delta))$ is negative and statistically significant at the $1 \%$ level in Model (1); a 1\% increase in population growth leads to $5.52 \%$ decrease in economic growth.

Table 4

The Estimated Long-run Coefficient Results

\begin{tabular}{|c|c|c|c|}
\hline Regressor & $\begin{array}{c}\text { Model (1): } \\
\text { ARDL }(2,2,2,1,2,1,2)\end{array}$ & $\begin{array}{c}\text { Model (2) : } \\
\text { ARDL }(2,2,2,2,2,2,2)\end{array}$ & $\begin{array}{c}\text { Model (3): } \\
\text { ARDL }(1,1,2,1,0,2)\end{array}$ \\
\hline C & $7.833(0.001)^{*}$ & $2.976(0.011)^{*}$ & $4.208(0.001)^{*}$ \\
\hline 1n he & $8.298(0.001)^{*}$ & & \\
\hline 1n $e e$ & $9.419(0.001)^{*}$ & & \\
\hline $\ln d t$ & & $1.695(0.114)$ & \\
\hline 1n $b b$ & & $-1.181(0.259)$ & \\
\hline 1n open & $4.439(0.011)^{* *}$ & $0.473(0.644)$ & $3.145(0.024)^{* *}$ \\
\hline 1n $G E$ & & $2.033(0.063)^{* *}$ & $3.564(0.004)^{*}$ \\
\hline 1n $F P$ & $6.187(0.003)^{*}$ & & $4.186(0.001)^{*}$ \\
\hline $\ln s_{k}$ & $7.648(0.002)^{*}$ & $3.314(0.046)^{* *}$ & $5.924(0.000)^{*}$ \\
\hline $\ln (n+g+\delta)$ & $-5.518(0.005)^{*}$ & $-1.503(0.157)$ & $4.246(0.001)^{*}$ \\
\hline
\end{tabular}

${ }^{*}, * *$ and ${ }^{* * *}$ denote significant at $1 \%, 5 \%$ and $10 \%$ significance levels. 
In Model (2), the distortionary taxation (1n $d t)$, budget balance (1n $b b)$, trade openness (1n open) and population $(1 \mathrm{n}(n+g+\delta))$ growth have no significant effects on real per capita GDP growth. The results also show that a $1 \%$ in government expenditure (1n GE) leads to $2.03 \%$ increase in economic growth. This indicates that the government expenditure in Malaysia has an important and statistically significant effect on economic growth at the 5\% level. Similar to Model (1), the results show that savings in physical capital has a positive and significant effect on real per capita GDP growth at 5\% level; a 1\% increase in savings leads to a $3.31 \%$ increase in economic growth.

In Model (3), the long run coefficients for openness (1n open), government expenditure (1n GE), fiscal policy (1n $F P$ ), savings in physical capital (investment) $\left(1 \mathrm{n} s_{k}\right)$, and population growth $(1 \mathrm{n}(n+g+\delta))$ are statistically significant at the $5 \%$ and $1 \%$ levels. Thus, a $1 \%$ increase in these variables lead to a $3.15 \%, 3.56 \%, 4.19 \%, 5.92 \%$ and $4.25 \%$ increase in economic growth, respectively.

As discussed earlier, the error correction term indicates the speed of the adjustment which restores equilibrium in the dynamic model. The ECM coefficient shows how quickly variables return to equilibrium and it should have a statistically significant coefficient with a negative sign (Pahlavani et. al., 2005). Bannerjee et. al. (1998) hold that a highly significant error correction term is a further proof of the existence of a stable long-run relationship. Therefore, having determined the long-run coefficients for each selected ARDL model, we derive the estimates for the error correction model.

The results are displayed in Table 5. The one-lagged error correction terms (ECM) in Model (1) and Model (3) are found to have the expected negative sign and highly statistically significant but not for Model (2). This confirms once again, the existence of co-integrated relationships among the variables of Model (1) and Model (3). The coefficients of ECM(-1) are equal to (-1.30) and (-1.17) for Model (1) and Model (3) respectively. They imply that deviations from the long-run growth rate in GDP per capita are corrected by $1.30 \%$ in Model (1) and $1.17 \%$ in Model (3) over the following year. This means that the adjustment takes place relatively. For example, the speed of adjustment is relatively high, especially in Model (1). Also, for these models, the realizations of the R-squared Adjusted are by far the highest. 


\section{Table 5}

Estimated Short-run Error Correction Model (ECM-ARDL); Dependent Variable:

\begin{tabular}{|c|c|c|c|c|c|}
\hline Regressor & $\begin{array}{c}\text { Model (1): ARDL } \\
(2,2,2,1,2,1,2)\end{array}$ & Regressor & $\begin{array}{c}\text { Model (2): ARDL } \\
(2,2,2,2,2,2,2)\end{array}$ & Regressor & $\begin{array}{c}\text { Model (3): ARDL } \\
(1,1,2,1,0,2)\end{array}$ \\
\hline C & $6.045(12.044)^{*}$ & $\mathrm{C}$ & $17.008(4.866)^{*}$ & C & $5.176(5.176)^{*}$ \\
\hline$\Delta \ln r g d p c_{t-1}$ & $-0.042(-0.579)$ & $\Delta \ln r g d p c_{t-1}$ & $-0.264(-1.013)$ & $\Delta \ln r g d p c_{t-1}$ & $-0.757(-3.976)^{*}$ \\
\hline$\Delta \ln r g d p c_{t-2}$ & $-1.109(-10.647)^{*}$ & $\Delta \ln r g d p c_{t-2}$ & $-2.129(-3.526)^{*}$ & $\Delta \ln r g d p c_{t-2}$ & - \\
\hline$\Delta \ln h e_{t}$ & $-0.0148(-0.586)$ & $\Delta \ln d t_{t}$ & $-0.050(-0.566)$ & $\Delta \ln G E_{t}$ & $-0.009(-3.528)^{*}$ \\
\hline$\Delta \ln h e_{t-1}$ & $-0.096(-2.907)^{* *}$ & $\Delta \ln d t_{t-1}$ & $0.124(1.826)$ & $\Delta \ln G E_{t-1}$ & $-0.043(-3.242)^{*}$ \\
\hline$\Delta \ln h e_{t-2}$ & $-0.296(-5.015)^{*}$ & $\Delta \ln d t_{t-2}$ & $0.242(2.388)^{* *}$ & $\Delta \ln F P_{t}$ & $-0.241(-1.031)$ \\
\hline$\Delta \ln e e_{t}$ & $0.014(0.523)$ & $\Delta \ln b b_{t}$ & $0.009(1.1600)$ & $\Delta \ln F P_{t-1}$ & $0.946(2.249)^{* *}$ \\
\hline$\Delta \ln e e_{t-1}$ & $0.129(3.556)^{*}$ & $\Delta \ln b b_{t-1}$ & $0.022(1.559)$ & $\Delta \ln F P_{t-2}$ & $1.714(3.775)^{*}$ \\
\hline$\Delta \ln e e_{t-2}$ & $0.281(4.887)^{*}$ & $\Delta \ln b b_{t-2}$ & 0.035 (1.434) & $\Delta \ln$ open $_{t}$ & $0.407(4.963)^{*}$ \\
\hline$\Delta \ln$ open $_{t}$ & $0.165(4.929)^{*}$ & $\Delta \ln$ open $_{t}$ & $0.670(4.032)$ & $\Delta \ln$ open $_{t-1}$ & $0.979(5.050)^{*}$ \\
\hline$\Delta \ln$ open $_{t-1}$ & $0.297(11.488)^{*}$ & $\Delta \ln$ open $_{t-1}$ & $0.188(1.492)$ & $\Delta S_{k_{t}}$ & $0.177(4.781)^{*}$ \\
\hline$\Delta \ln$ open $_{t-2}$ & & $\Delta \ln$ open $_{t-2}$ & $1.890(4.523)^{*}$ & $\Delta S_{k_{t-1}}$ & $-0.062(-2.372)^{* *}$ \\
\hline$\Delta \ln F P_{t}$ & $-0.254(-1.823)^{* * *}$ & $\Delta \ln G E_{t}$ & $-0.001(-0.430)$ & $\Delta S_{k_{t-2}}$ & $0.038(1.627)$ \\
\hline$\Delta \ln F P_{t-1}$ & $0.429(2.897)^{* *}$ & $\Delta \ln G E_{t-1}$ & $0.028(1.025)$ & $\Delta \ln (n+g+\delta)_{t}$ & $0.773(2.699)^{* *}$ \\
\hline$\Delta \ln F P_{t-2}$ & $0.864(3.964)^{*}$ & $\Delta \ln G E_{t-2}$ & $-0.140(0.109)$ & $\Delta \ln (n+g+\delta)_{t-1}$ & $0.068(0.646)$ \\
\hline$\Delta S_{k_{t}}$ & $0.261(10.082)^{*}$ & $\Delta S_{k_{t}}$ & $-0.024(-0.289)$ & & \\
\hline$\Delta S_{k_{t-1}}$ & $0.073(6.169)^{*}$ & $\Delta S_{k_{t-1}}$ & $-0.144(-2.059)^{* * *}$ & & \\
\hline$\Delta S_{k_{t-2}}$ & & $\Delta S_{k_{t-2}}$ & $-0.178(-1.816)$ & & \\
\hline$\Delta \ln (n+g+\delta)_{t}$ & $0.041(0.816)$ & $\Delta \ln (n+g+\delta)_{t}$ & $0.147(1.024)$ & & \\
\hline$\Delta \ln (n+g+\delta)_{t-1}$ & $-0.149(-4.174)^{*}$ & $\Delta \ln (n+g+\delta)_{t-1}$ & $-0.207(-1.618)$ & & \\
\hline$\Delta \ln (n+g+\delta)_{t-2}$ & $-0.249(-2.392)^{* *}$ & $\Delta \ln (n+g+\delta)_{t-2}$ & $-0.555(0.592)$ & & \\
\hline$e c m_{t-1}$ & $1.307(-10.019)^{*}$ & $e c m_{t-1}$ & $0.054(-4.936)$ & $e c m_{t-1}$ & $-1.174(-7.432)^{*}$ \\
\hline $\mathrm{R}^{2}$-Adjusted & 0.993 & $\mathrm{R}^{2}$-Adjusted & 0.962 & $\mathrm{R}^{2}$-Adjusted & 0.950 \\
\hline DW-statistic & 1.562 & DW-statistic & 2.246 & DW-statistic & 2.607 \\
\hline SBC & 111.045 & SBC & 86.425 & SBC & 76.287 \\
\hline
\end{tabular}

Notes. ( ) refer to $t$-statistics; ${ }^{*}, * *$ and ${ }^{* * *}$ denote significant at $1 \%, 5 \%$ and $10 \%$ significance levels.

We conclude that Table 5 contains the final estimation results of the errorcorrection model based on ARDL approach. These results in Model (1) and Model (3) give us some intuitions on the order of magnitude of the impacts of openness and fiscal policy on economic growth.

\section{CONCLUSION}

Trade openness is found to have an important affect on economic growth. This is consistent with the prediction of most international trade 
theories that trade openness is an important engine for economic growth. Vamvakidis (2002) and Harrison (1996), amongst others, report that trade openness affects economic growth positively. Trade openness can lead to an increase in specialization that will accelerate productivity growth by enhancing economies of scale. Moreover, an economy that is more open is expected to face more competition and thus stimulates productivity, which in turn promotes economic growth. Therefore, trade openness is beneficial for the growth of the Malaysian economy. For example, the ASEAN Free Trade Agreement (AFTA) is expected to further increase intra-ASEAN trade when the tariffs are lowered or removed. This would be crucial as an impetus for the Malaysian economy to grow further.

The recent models of government expenditure and economic growth developed by Barro (1990) and Devarajan et al. (1996) point to the functional composition of government expenditure as a decisive factor. In our study, we have focused on government expenditure on health and education. The analyses of these government expenditure show that the authorities do make active use of government expenditure. This implies that government expenditure, as an economic tool, is practically possible and can be effective in influencing the real per capita GDP.

We assessed the empirical evidence on the link between fiscal policy and growth by considering five policy areas: public sector wages and salaries, expenditure on other goods and services, transfers and subsidies, interest payment on government debt, capital expenditure (minus government expenditure on health, education and defense), tax revenue, non-tax revenue, and grant. The analyses of fiscal policy in the Malaysian economy show that the authorities do make active use of fiscal policy to influence the real per capita GDP. Thus, there is a rationale for the use of fiscal policy in promoting growth.

Our studies on distortionary taxation and budget balance are not similar to other studies. Ours is influenced by the new growth theories, and make use of a cross country regression to assess the impacts of distortionary taxation and budget balance on real per capita GDP (economic growth) at the macro level. Our results through ARDL approach demonstrate insignificant relationships between the level of the distortionary taxation and budget balance and the growth rate of GDP per capita, implying that distortionary taxation and budget balance do not have a significant impact on economic growth in Malaysia. On the other hand, we found that savings in physical capital (investment) and population growth rate significantly influenced GDP per capita. 


\section{REFERENCES}

Bannerjee, A., Dolado, J., \& Mestre, R., (1998). Error-correction mechanism tests for co-integration in single equation framework. Journal Time Series Analysis, 19, 267-283.

Barro, R. J., (1990). Government spending in a simple model of endogenous growth. Journal of Political Economics 98, 103-125.

Barro, R.J., \& Sala-I-Martin, X. (1995). Economic growth. McGraw-Hill: New York.

Bleaney, M., Gemmell, N., \& Kneller, R. (2001). Testing the endogenous growth model: Public expenditure, taxation, and growth over the long-run. Canadian Journal of Economics, 34(1), 36-57.

Caselli, F., Esquivel, G., \& Lefort, F. (1996). Reopening the convergence debate: A new look at cross-country growth empirics. Journal of Economic Growth, 1, 363-389.

Cashin, P. (1995). Government spending, taxes, and economic growth. (1) International Monetary Fund Staff Papers 42, 237-269.

„Chen, P., \& Gupta, R. (2006). An investigation of openness and economic growth using panel estimation. University of Pretoria, Working Paper 2006-22.

Devarajan, S., Swaroop, V., \& Zou, H. (1996). The composition of public expenditure and economic growth. Journal of Monetary Economics, 37(2), 313-344.

Demetriades, P., \& Law, S.H. (2006). Finance, institutions and economic development. International Journal of Finanace and Economics, 11, $1-16$.

Edwards, S., (1998). Openness, productivity and growth: What do we rally know? Economic Journal, 108, 383-398.

Engen, E., \& Skinner, J. (1993). Fiscal Policy and Economic Growth. Manuscript (University of Virginia, Charlottesville, VA).

Folster, S., \& Henrekson, M., (2001). Growth effects of government expenditure and taxation in rich countries. European Economic Review, 45, 1501-1520.

Gerson, P. (1998). The impact of fiscal policy variables on output growth. International Monetary Fund. Working Paper 98/1.

Glomm, G., \& Ravikumar, B. (1997). Productive government expenditure and long-run growth. Journal of Economic Dynamic and Control, 21, 183-204.

Ghura, D., \& Hadjimichael, M.T. (1996). Growth in Sub-Saharan African. IMF Staff Paper, 43, 605-635. 
Hansson, P., \& Hendrekson, M. (1994). A new framework for testing the effect of government spending on growth and productivity. Public Choice, 31, 381-401.

Harrion, A., (1996). Openness and growth: A time-series, cross-country analysis for developing countries. Journal of Development Economic, 48, 419-449.

Hoeffler A.K. (2002). The augmented Solow Model and the African growth debate. Oxford Bulletin of Economics and Statistics, 64(2), 0305-9049.

Islam, N. (1995). Growth empirics: A panel data approach. Quarterly Journal of Economics, 110, 1127-1170.

Jha, R., (2007). Fiscal policy in developing countries: A synoptic view. ASARC Working Paper 2007/01.

Kneller, R., Bleaney M. F., \& Kneller, N. (1999). Fiscal policy and growth: Evidence from OECD Countries. Journal of Public Economics 74, 171-190.

Knight, M., Loayza, N., \& Villanueva, D. (1993). Testing the neoclassical theory of economic growth, a panel data approach. International Monetary Fund Staff Paper, 40(3).

Landau, D., (1997). Government Expenditure, Human Capital Creation and Economic Growth. Journal of Public Budgeting, Accounting $\mathcal{E}$ Financial Management, 9(3), 467-487.

Levine, R., \& Renelt, D. (1992). A sensitivity analysis of cross-country growth regressions. American Economic Review, 82, 942-63.

Lloyd, P.J. (1999). The Global Economy in PJ. Lloyd (d.), International Trade Opening and the Formation of the Global Economy, Cheltenham, the United Kingdom: Edward Elgar.

Mankiw, G., Romer, D., \& Weil, D. (1992). A contribution to the empirics of economic growth. Quarterly Journal of Economics 107, 407-437.

Narayan, P.K., (2005). The saving and investment nexus for China: Evidence from co-integration tests. Applied Economics, 37, 19791990.

Pahlavani, M., Wilson E., \& Worthington A.C., (2005). Trade-GDP Nexus in Iran: An application of autoregressive distributed lag (ARDL) model. American Journal of Applied Sciences, 2(7), 1158-1165.

Pesaran, M. H., Pesaran, B., (1997). Working with Microfit 4.0: Interactive econometric analysis. Oxford: Oxford University Press.

Pesaran, M. H., \& Y. Shin, (1995). An autoregressive distributed lag modelling approach to co-integration analysis. DAE Working Paper No. 9514, Department of Applied Economics (Cambridge: Cambridge University). 
Pesaran, M.H., \& Smith, R.J., (1998). Structural analysis of co-integration VARs. Journal of Economic Survey, 12, 471-505.

Pesaran, M. H., Shin, Y., \& Smith, R.J., (2001). Bounds testing approaches to the analysis of level relationships. Journal of Applied Econometrics 16(3), 289-326.

Ramirez, M.D., \& Nazmi, N., (2003). Public investment and economic growth in Latin America: An empirical test. Review of Development Economics, 7(1), 115-126.

Vamvakidis, A., (1998). Regional integration and economic growth. The World Bank Economic Review, 12(2), 251-270. (2002). How robust is the growth-openness connection? Historical Evidence. Journal of Economic Growth, 7(1), 57-80.

Yanikkaya, H., (2003). Trade openness and economic growth: A cross- country empirical investigation. Journal of Development Economics, 72(1), 57-89.

Yasin, M. (2003). Public spending and economic growth: Empirical investigation of Sub-Saharan Africa. Southwestern Economic Review, 59-68. 


\section{Appendix 1: CUSUM and CUSUM SQ for Equation 6 to Equation 8}

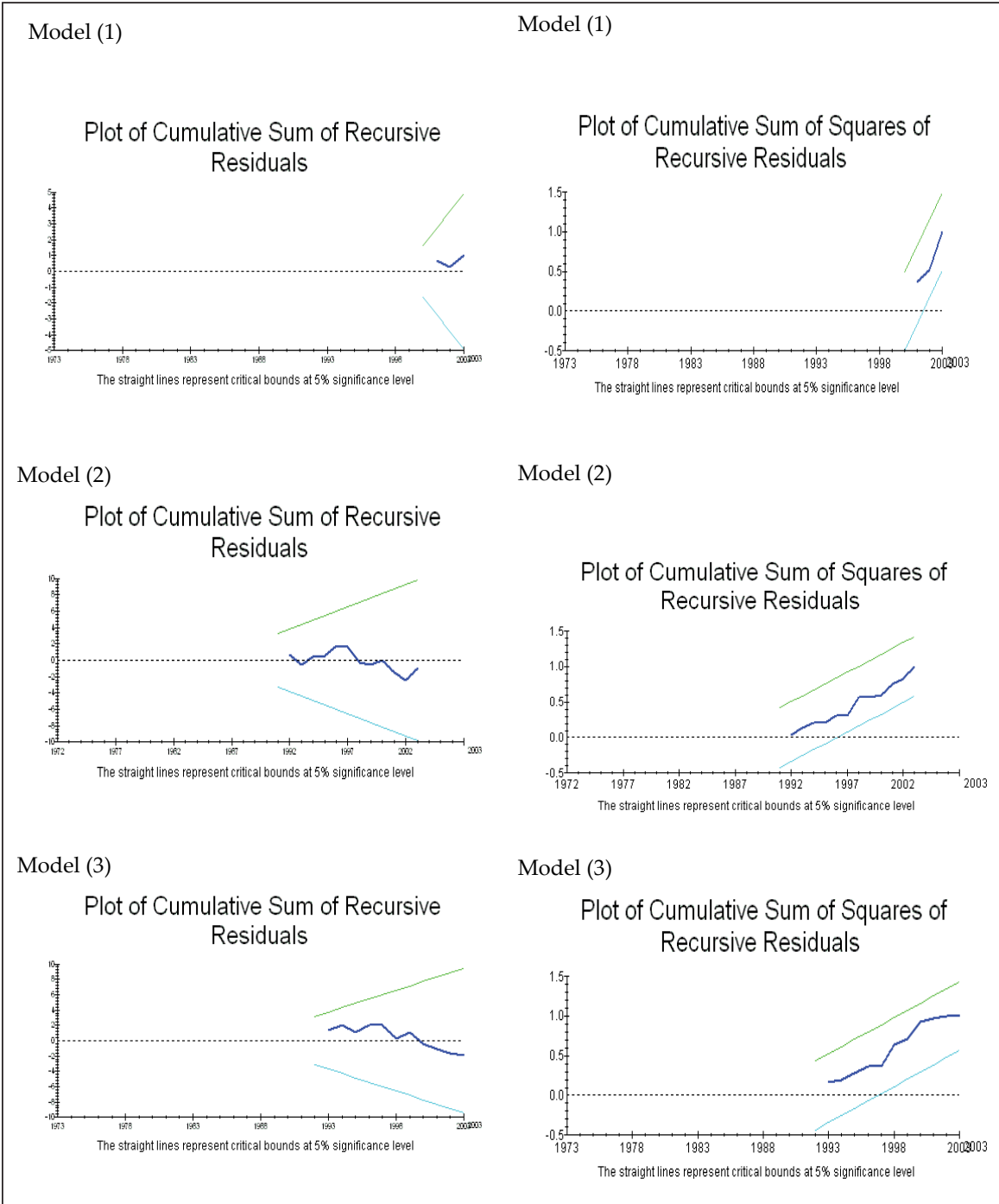

